\title{
Evaluation of Physical and Mental Quality of Life of Motorcycle Taxi Drivers
}

\author{
Arlete de Carvalho Félix, Alexandra Maria Almeida Carvalho Pinto, \\ Albert Schiaveto de Souza \\ Departamento do Programa de Pós-Graduação em Saúde e Desenvolvimento na Região Centro Oeste, Campo \\ Grande, Mato Grosso do Sul, Brasil \\ Email: arlete175@hotmail.com
}

Received 22 January 2016; accepted 21 March 2016; published 24 March 2016

\begin{abstract}
Motorcycle taxi drivers are workers who use motorcycle to carry passengers. Objectives: to identify the sociodemographic profile and evaluate the physical and mental quality of life of motorcycle taxi drivers. Methods: Cross-sectional study, held in Campo Grande, Mato Grosso do Sul-Brazil, from May to July 2015 with 301 participants. To calculate the sample size, the margin of error was $5 \%$, confidence level, $95 \%$; and the drivers were randomly selected. For data collection, two instruments were used: the demographic questionnaire and the SF-36 Health Status Questionnaire. Results: Among the 301 respondents, predominance fell on males $(98.7 \%, n=297)$, married or in a stable relationship $(63.5 \%, n=191)$, with completed high school education $(44.9 \%, n=135)$. More than half felt discomfort while working $(52.8 \%, n=159)$. Of those with diagnosed disease the predominant type of disease was hypertension $(55.5 \%, n=30)$. When male and female were compared, men had lower average in the mental health aspect $(63.39 \pm 13.22)$; and women, in the emotional aspect $(41.66 \pm 31.91)$. There were significant differences in the scores of physical functioning $(p=0.002)$, bodily pain $(0.043)$ and general health perceptions $(p=0.003)$ of the drivers reporting disease, compared to those who did not reported it. Conclusion: The studied motorcycle taxi drivers are mostly male, married, with high school education. Regarding quality of life, men had lower perception in the general mental health aspect whereas women showed lower perception in the emotional aspects. The individuals with disease had lower perceived quality of life in the physical functioning, bodily pain and general health concepts.
\end{abstract}

\section{Keywords}

Disease, Motorcycle Taxi Drivers, Quality of Life

\section{Introduction}

Motorcycle taxi drivers are professionals who drive taxi motorcycles as a way of living. This means of urban people transportation is [1] used not only in Brazil, but in countries around the world for being agile and inexpensive [2].

It can be seen that this means of transportation has become relevant in providing service not only to the Bra- 
zilian society, but to all others who recognize this activity as a profession.

Although the drivers are professionals who play an important role in providing service to society, they are faced with many occupational hazards in the workplace. Working factors can cause injury, disease or disability, or compromise the welfare of the worker and the community. Among these risks, several aspects can be listed: chemical, physical, biological, ergonomic, psychological, social, security and environmental factors [3].

All these factors can affect the quality of physical and mental life of the workers, either directly or indirectly.

The World Health Organization (WHO) defines quality of life as the individual's perception of their position in life in the context of culture and value systems in which they live and in relation to their goals, expectations, standards and concerns [4].

The assessment of quality of life allows knowing the subjects' perception of the possible impacts on their well-being [5] considering the different concepts measuring physical and mental health.

Considering the above, the intention of this study was to obtain an answer to the following question: How is the quality of life, from the point of view of physical and mental health, of motorcycle taxi drivers in Campo Grande-MS?

The aim of this study, then, was to identify the sociodemographic profile and evaluate the professionals' physical and mental quality of life.

\section{Materials and Methods}

This was a cross-sectional study held with motorcycle taxi drivers in Campo Grande-Mato Grosso do Sul, from May to July 2015.

With a population of 980 motorcycle taxi drivers, the sample consisted of 332 individuals, including $20 \%$ for losses, margin of error $5 \%$ and confidence level $95 \%$. The simple random probability sampling technique was used. For the selection of motorcycle taxi drivers $(n=332)$, numbers one (1) to 980 was set to each professional present in the nominal list of registered motorcycle taxi drivers held by the Municipal Agency of Transport and Traffic-AGETRAN. After the shuffle, a list was made with the names of 332 motorcycle taxi drivers containing address and the telephone number of the taxi ranks.

The study included the motorcycle taxi drivers selected by shuffle; those who filled the questionnaires incompletely were excluded, then considering 31 losses (9.6\%) and yielding the final sample of 301 individuals.

Data were collected at the motorcycle taxi ranks with the application of two questionnaires (the socio-demographic questionnaire and the SF-36 Health Status Questionnaire).

The sociodemographic questionnaire collected sociodemographic data and variables related to the diagnosed / chronic diseases.

The SF-36 generic questionnaire for assessing quality of life is an instrument translated into and culturally adapted for the Brazilian population according to internationally recommended methods [6], containing 36 questions grouped in eight concepts measuring different health states, summarized in two components (physical and mental health) [7].

The first component is formed by the following concepts: physical functioning, bodily pain and general health perceptions. The second component includes the concepts vitality, social functioning, emotional aspects and general mental health [8].

Each concept has scores 0 - 100, with zero (0) corresponding to the worst condition and one hundred (100) to the best health status [7].

Statistical analysis was performed using SPSS software, version 22, considering a 5\% significance level.

To describe the quantitative variables, the average and the average standard deviation were used for categorical variables and relative and absolute frequencies, \% (n).

The comparison between male and female motorcycle taxi drivers, for the scores of SF-36 different concepts, was drawn using the Student's t test.

The study was approved by the Ethics Committee of the Federal University of Mato Grosso do Sul, CAAE No. 39550214.0.0000.0021, and the participants signed a free and informed consent form.

\section{Results}

Interviews were conducted with 332 motorcycle taxi drivers, but 31 (9.6\%) were excluded because of inadequate filling of the instruments, resulting in a final sample of 301 respondents. 
Among the participants, males predominated $(98.7 \%, \mathrm{n}=297)$. Regarding marital status, $63.5 \%(\mathrm{n}=191)$ were married or in a stable relationship; as to education, $44.9 \%(n=135)$ had completed high school (Table 1).

Table 2 shows results for the health of the surveyed motorcycle taxi drivers. These data show that $52.8 \%$ ( $\mathrm{n}=$ 159) of the subjects felt discomfort while exercising the profession. Among the types of discomfort reported, back lumbar/pain prevailed $(73.0 \%, \mathrm{n}=116)$. The questions related to diseases revealed that $17.9 \%(\mathrm{n}=54)$ reported having some type of diagnosed disease and, among these, the prevalent disease was hypertension/high blood pressure $(55.5 \% \mathrm{n}=30)$.

Table 3 shows the comparison between genders as to scores in the various concepts of the SF-36. In the physical functioning concept, the score was significantly higher in males than in females $(p=0.002)$; in the others there was no statistically significant difference (Student's t test, $\mathrm{p}$ value ranging between 0.114 and $0.878)$.

In Table 4 a statistically significant difference was seen in physical functioning (Student's t-test, $p=0.002$ ), bodily pain $(p=0.043)$ and general health perception $(p=0.003)$ in the participants who reported disease and those who did not. In the other concepts, there was no difference in the SF-36 scores ( $p$ value ranging between 0.190 and 0.807$)$.

\section{Discussion}

In this study there was predominance of males, married or in a stable relationship. Others studies with this population showed a profile similar to the findings of this study [2] [9].

With regard to schooling, individuals with complete high school prevailed. This result corroborates the findings of research conducted in another country and another region of Brazil [2].

In this study most motorcycle taxi drivers felt discomfort when working. A study conducted with motorcycle taxi drivers on complaints about skeletal muscles showed that, among the professionals surveyed, 50\% reported pain in some part of the body, and the back was the most affected region [10].

Table 1. Sociodemographic characteristics (gender, marital status and schooling), Campo Grande-MS, 2015, (n= 301).

\begin{tabular}{lc}
\multicolumn{1}{c}{ Variable } & \%(n) \\
\hline Gender & $1.3(4)$ \\
Feminine & $98.7(297)$ \\
Masculine & \\
Marital status & $63.5(191)$ \\
Married/stable relationship & $10.3(31)$ \\
Divorced & $0.3(1)$ \\
Other & $24.9(75)$ \\
Single & $1.0(3)$ \\
Widowed & \\
Schooling & $18.9(57)$ \\
Incomplete elementary school & $13.6(41)$ \\
Complete elementary school & $9.0(27)$ \\
incomplete high school & $44.9(135)$ \\
complete high school & $11.0(33)$ \\
incomplete university & $2.3(7)$ \\
complete university & $0.3(1)$ \\
Specialization &
\end{tabular}

Result presented in percentage (\%) and number (n). 
Table 2. Results referring to the motorcycle taxi drivers' health, Campo Grande-MS, 2015 (n = 301).

\begin{tabular}{|c|c|}
\hline Variable & $\%(n)$ \\
\hline \multicolumn{2}{|l|}{ Disconfort } \\
\hline Yes & $52.8(159)$ \\
\hline No & $47.2(142)$ \\
\hline Type of Discomfort ( $\left(^{*}\right)$ & $(\mathrm{n}=159)$ \\
\hline Back/lumbar pain & 73.0(116) \\
\hline Pain in the arms & $30.2(48)$ \\
\hline Pain in the legs & $27.0(43)$ \\
\hline Headache & 11.3(18) \\
\hline Sickness/nausea & $1.2(2)$ \\
\hline Dizziness & $2.0(3)$ \\
\hline Stress: nervousness, irritation & $36.5(58)$ \\
\hline Others & $6.3(10)$ \\
\hline \multicolumn{2}{|l|}{ Reported disease } \\
\hline Yes & $17.9(54)$ \\
\hline No & $82.1(247)$ \\
\hline Type of disease $\left(^{* *}\right)$ & $(n=54)$ \\
\hline Hypertension/high blood pressure & $55.5(30)$ \\
\hline Diabetes mellitus & $11.1(6)$ \\
\hline Cardiopathy & $3.7(2)$ \\
\hline Osteomuscular diseases Problems in spine, arms, legs, knees, shoulders etc. & $3.3(10)$ \\
\hline Others & 22.2(12) \\
\hline
\end{tabular}

*The subjects could report more than one type of discomfort.

Table 3. Results referring to the SF-36 scores as to gender ( $\mathrm{n}=301)$. Campo Grande-MS, 2015.

\begin{tabular}{|c|c|c|c|}
\hline \multirow{2}{*}{ Concepts SF-36 } & \multicolumn{2}{|c|}{ Sexo } & \multirow{2}{*}{ P value } \\
\hline & Masculine $(n=297)$ & Feminine $(n=4)$ & \\
\hline \multicolumn{4}{|l|}{ Physical health } \\
\hline Physical functioning & $83.65 \pm 18.06$ & $55.00 \pm 29.15$ & $0.002^{*}$ \\
\hline Physical aspects & $71.12 \pm 33.91$ & $56.25 \pm 23.93$ & 0.383 \\
\hline Bodily pain & $73.67 \pm 22.76$ & $62.00 \pm 22.70$ & 0.309 \\
\hline General health perceptions & $72.06 \pm 17.75$ & $73.50 \pm 18.52$ & 0.873 \\
\hline \multicolumn{4}{|l|}{ Mental health } \\
\hline Vitality & $69.64 \pm 20.67$ & $71.25 \pm 27.50$ & 0.878 \\
\hline Social functioning & $78.83 \pm 12.60$ & $68.75 \pm 16.13$ & 0.114 \\
\hline Emotional health & $70.25 \pm 37.49$ & $41.66 \pm 31.91$ & 0.130 \\
\hline Mental health & $63.39 \pm 13.22$ & $67.00 \pm 31.55$ & 0.834 \\
\hline
\end{tabular}

The results are presented in average \pm average standard deviation. $P$ value in the Student's t-test. 
Table 4. Results referring to SF-36 scores as to disease variable ( $\mathrm{n}=301)$. Campo Grande-MS, 2015.

\begin{tabular}{|c|c|c|c|}
\hline \multirow{2}{*}{ Concepts SF-36 } & \multicolumn{2}{|c|}{ Disease } & \multirow{2}{*}{ P value } \\
\hline & Yes $(n=54)$ & No $(n=247)$ & \\
\hline \multicolumn{4}{|l|}{ Physical health } \\
\hline Physical functioning & $74.72 \pm 22.47$ & $85.14 \pm 16.96$ & $0.002^{*}$ \\
\hline Physical aspects & $69.90 \pm 36.78$ & $71.15 \pm 33.21$ & 0.807 \\
\hline Bodily pain & $67.85 \pm 23.87$ & $74.75 \pm 22.37$ & $0.043^{*}$ \\
\hline General health perceptions & $65.64 \pm 15.94$ & $73.49 \pm 17.81$ & $0.003^{*}$ \\
\hline \multicolumn{4}{|l|}{ Mental health } \\
\hline Vitality & $68.70 \pm 20.60$ & $69.87 \pm 20.78$ & 0.707 \\
\hline Social functioning & $78.00 \pm 12.12$ & $78.84 \pm 12.81$ & 0.661 \\
\hline Emotional health & $69.13 \pm 37.11$ & $70.04 \pm 37.68$ & 0.873 \\
\hline Mental health & $65.62 \pm 12.05$ & $62.96 \pm 13.78$ & 0.190 \\
\hline
\end{tabular}

The results are presented in average \pm average standard deviation. P value in the Student's t-test.

As for the quality of life in general, it can be said that the male motorcycle taxi drivers who did not report disease were those with better perception of quality of life.

On assessing the specific scores of quality of life, the best perception of quality of life for the males was the physical functioning concept and, for the females, the general health perception concept (Table 3). These concepts form part of the physical health component. On the other hand, the less indicated concept by males was mental health; and by females, emotional aspects, both belonging to the mental health category. The scores of each concept ranged from 0 to 100 and the higher the average in each scale the better health status and vice versa [5].

When comparing the quality of life in relation to gender, there was a statistically significant difference in physical functioning concept, suggesting that men have better perception of quality of life in this concept.

Other researchers, on assessing the quality of life of motorcycle taxi drivers, found that physical functioning had reports similar to the results obtained in this work although gender was not analyzed separately [11].

When comparing the drivers who reported disease with those who did not, in relation to the averages of each concept evaluating quality of life, the latter showed better perception of quality of life in physical functioning, bodily pain and general health perceptions, and the concept with the highest score is physical functioning (Table 4). Another study addressing the same population showed similar values in the physical functioning concept [11].

The type of disease reported by the drivers was also analyzed. Of the 54 individuals who reported having some kind of disease, high blood pressure prevailed. Although this percentage is not representative compared with the total number of the surveyed sample, the type of disease that prevailed among the motorcycle taxi drivers who reported having some kind of disease is remarkable.

This finding corroborates another study that, on assessing the cardiovascular health and quality of life of motorcycle taxi drivers, found the presence of hypertension in most workers [11].

\section{Conclusion}

The motorcycle taxi drivers are mostly males with a high school degree, married or in a stable relationship. A large number of them feel discomfort while exercising the profession. The drivers with some type of diagnosed disease have a lower perception in the quality of life assessment in physical functioning, bodily pain and general health perceptions concepts than those without the disease. When comparing the quality of life of male and female motorcycle taxi drivers, men have better perception in physical capacity. On the other hand, the mental health concept presents the poorest perception in the professionals' specific assessment. Males showed a lower result in the mental health concept, and women in the field emotional aspects. The lowest rank for males fell on 
the mental health concept and, for females, on emotional health.

\section{Acknowledgements}

We would like to thank the Democratic Republic of São Tomé e Príncipe, the Federative Republic of Brazil, the Federal University of Mato Grosso do Sul, the Higher Education Personnel Improvement Coordination-CAPES, and the Municipal Agency of Transport and Traffic-AGETRAN. Also the motorcycle taxi drivers of Campo Grande-MS, Rosalino Sanca, Karlla Guerra, David Machate, Professor Wilson José Gonçalves, Professor Maria Lucia Ivo, Professor Iandara Schettert Silva and, especially, my parents, Domingos Martins das Neves Felix and Sebastiana Hope Oak. And also the Universe, for life.

\section{References}

[1] Teixeira, J.R.B., Santos, N.A., Sales, Z.N., Moreira, R.M., Boery, R.N.S.O., Boery, E.M., et al. (2014) Use of Personal Protective Equipment for Motorcycle Taxi Drivers: Perception of Risks and Associated Factors. Cad Saúde Pública, 30, 885-890. http://www.scielo.br/pdf/csp/v30n4/0102-311X-csp-30-4-0885.pdf http://dx.doi.org/10.1590/0102-311X00129913

[2] Avila, I.Y.C., Herrera, B.G. and Gómez, H.P. (2013) Work and Health Conditions in Motorcycle Taxi Drivers Cartagena-Colombia. Salud Uninorte. Barranquilla, 29, 514-524. http://www.scielo.org.co/pdf/sun/v29n3/v29n3a12.pdf

[3] Oliveira, T.S., Filho, S.A.M. and Araújo, G.F. (2012) Conhecimento de Mototaxistas quanto aos riscos ocupacionais. Revista Baiana de Saúde Pública, 36, 899-918. http://inseer.ibict.br/rbsp/index.php/rbsp/article/viewFile/787/386

[4] The WHOQOL Group (1998) The World Health Organization Quality of Life Assessment (WHOQOL): Development and General Psychometric Properties. Soc Sci Med, 46, 1569-1585.

http://www.psychology.hku.hk/ftbcstudies/refbase/docs/thewhoqolgroup/1998/71_TheWHOQOLGroup1998.pdf http://dx.doi.org/10.1016/S0277-9536(98)00009-4

[5] Silva, K.J., Cordeiro, G.D., Rossinoli, C., Galhardo, M.L. and Faganello, M.M. (2015) Evaluation of Life Quality and Dyspnea Intensity on Chronic Airway Diseases Patients in Pulmonary Rehabilitation Program. Scientific Research Publishing, 4, 10-15.

[6] Ciconelli, R.M., Ferraz, M.B., Santos, W., Meinão, I. and Quaresma, M.R. (1999) Tradução para a língua portuguesa e validação do questionário genérico de avaliação de qualidade de vida SF-36 (Brasil SF-36). Rev Bras Reumatol, 39, 143-150.

http://www.ufjf.br/renato_nunes/files/2014/03/Valida\%C3\%A7\%C3\%A3o-do-Question\%C3\%A1rio-de-qualidade-deVida-SF-36.pdf

[7] Ware, J.E. and Kosinski, M. (2001) Interpreting SF-36 Summary Health Measures: A Response. Qual Life Res, 10, 415-420. http://www.sf-36.org/news/qolrsupplement.pdf http://dx.doi.org/10.1023/A:1012588218728

[8] Ware, J.E. SF-36 ${ }^{\circledR}$ Health Survey Update. http://www.sf-36.org/tools/sf36.shtml\#trans

[9] Teixeira, J.R.B., Boery, E.N., Casotti, C.A., Araújo, T.M., Pereira, R., Ribeiro, Í.J.S., et al. (2015) Association between Psychosocial Aspects of Work and Quality of Life among Motorcycle Taxi Drivers. Cad Saúde Pública, 31, 97-110. http://www.scielosp.org/pdf/csp/v31n1/0102-311X-csp-31-01-00097.pdf

[10] França, D.X.S. and Bakke, H.A. (2015) Queixas musculoesqueléticas em mototaxistas. Rev. de Atenção à Saúde, 13, 26-33. http://seer.uscs.edu.br/index.php/revista_ciencias_saude/article/view/2789/1779

[11] Oliveira, B.G., Ribeiro, Í.J.S., Bomfim, E.S., Boery, R.N.S.O., Casotti, C.A. and Boery, E.N. (2015) Saúde cardiovascular e qualidade de vida de mototaxistas. Ciênc Saúde, 22, 33-38. file:///C:/Users/ea/Downloads/30-108-1-PB\%20(2).pdf http://dx.doi.org/10.17696/2318-3691.22.1.2015.30 